\title{
Effect of plasmochemically activated aqueous solution on process of food sprouts production
}

\author{
Oleksandr Pivovarov, Olena Kovaliova, Vitalii Koshulko
}

\section{Dnipro State Agrarian and Economic University, Dnipro, Ukraine}

\section{Keywords: \\ Sprouts \\ Activation \\ Intensifier \\ Germination \\ Legumes}

\section{Article history: \\ Received 02.03.2020 \\ Received in revised \\ form 28.06.2020 \\ Accepted 30.09.2020}

\section{Corresponding author:}

Oleksandr Pivovarov

E-mail:

apivo@ua.fm

DOI: $10.24263 / 2304-$

974X-2020-9-3-7

\section{Abstract}

Introduction. The effect of plasmochemically activated aqueous solutions on the process of production of food sprouts of legume crops is studied. The paper presents the characteristic of activated aqueous solutions, their effect on the germination process and microbiological status of sprouts.

Materials and methods. Grain of legumes (peas, soybeans, chickpeas, kidney beans, lentils, beans, lupines) was sprouted with the use of plasmochemically activated aqueous solutions as an intensifier of germination. In order to determine the amino acid and vitamin composition of sprouts, the method of ion-exchange liquid column chromatography was used.

Results and discussion. Legume germination energy and capacity increased with the use of plasmochemically activated aqueous solutions. At the optimal concentration of peroxides equal to $400 \mathrm{mg} / \mathrm{l}$, the germination energy increased by $10-12 \%$, and the germination capacity featured growth by $8-10 \%$. Monitoring of the sprout length showed the increase in length from 6 to $14 \mathrm{~mm}$. Control of weight of sprout biomass also demonstrated positive results, that is, $4-16 \%$ sprout weight gain, depending on the crop (peas $-8 \%$; soybeans $-10 \%$; chickpeas $7 \%$; kidney beans $-14 \%$; lentils $-4 \%$; beans $-16 \%$; lupines $10 \%)$.

Study of the microbiological status of sprouts showed stable disinfecting action of plasmochemically activated aqueous solutions owing to the presence of hydrogen peroxide in their composition (100-700 mg/l). No pathogenic microflora was recorded on the sprouts treated with plasmochemically activated aqueous solutions with the peroxide concentration of $400 \mathrm{mg} / \mathrm{l}$ and more (Aspergillus, Alternaria, Penicillium, Fusarium, Mucor).

Owing to the usage of plasmochemically activated aqueous solutions, legume sprouts demonstrated the increase in the content of $\mathrm{B}$ group vitamins $\left(\mathrm{B}_{1}, \mathrm{~B}_{2}, \mathrm{~B}_{3}, \mathrm{~B}_{6}, \mathrm{~B}_{12}\right)$, as well as PP, E, C, A. The number of amino acids increased by $4-52 \%$. It is explained by more active development of legume sprouts, while using the intensifier of germination, i.e. plasmochemically activated aqueous solutions.

Conclusions. Usage of plasmochemically activated aqueous solutions is a promising process technology for obtaining highquality product rich in amino acids and vitamins. 


\section{Introduction}

Sprouts obtained from different crops have a specific set of nutrients, vitamins and microelements [1]. Grain crops are the most popular ones for germination [2]. The important technological aspect is the expansion of the range of crops for obtaining of food sprouts and their inclusion in the human diet [3].

The promising areas of intensification of the traditional technology for producing food sprouts are focused on creation of the favorable conditions for the germination of grain material and reduction of the duration of the process of sprout production by optimization of parameters of soaking and germination [4]. However, the modern intensifiers have a chemical nature and can adversely affect the finished product quality.

In order to intensify the technology for obtaining of food sprouts, a number of methods to activate the germination of grain material are used [5]: physical methods (ultrasonic waves, ionizing radiation, electromagnetic fields, incoherent red light) [6], chemical methods (diammonium phosphate, potassium bromide), physical-chemical methods (plasmochemical treatment of aqueous solutions, usage of ozonized aqueous solutions) and microbiological methods (enzyme preparations) [7].

Popular methods of intensification of the food sprouts' production technology include the use of germination bio-stimulants [8], among which organic acids are the most common (gibberellic acid, lactic acid, ferulic acid, indole acetic acid) [9]. Application of the above acids was studied in the malt technology only; no information of that kind is available for the production of food sprouts.

Organic acids mentioned below are used in the process of grain material germination: malic acid, racemic acid, citric acid [10], succinic acid, nicotinic acid, folic acid and their complexes [11]. Fruit acids are widely used in the germination process [12]. However, all these intensive technologies involve chemical compounds in the germination process, which does not allow obtaining completely safe product [13].

High quality of the obtained germinated grain raw materials is an important aspect in the implementation of intensive germination technologies [14]. It is of particular importance for the production of germinated grain [15], since it is used fresh. Furthermore, considerable attention is given to the microbiological status of food sprouts because of its effect on the quality and duration of storage [16]. This is due to the fact that in the process of germination a variety of microflora, including pathogenic one, develops on the grain surface [17]. Therefore, the prospects of finding new multi-purpose intensifiers of the grain germination in order to obtain high-quality food sprouts represent an urgent problem of the grain processing industry [18]. Versatility and safety of the germination intensifiers is of the utmost importance in this context [19]. So, the search for the intensifier mentioned above is a highpriority issue.

The usage of plasmochemically activated aqueous solutions [20] in the food industry [21] and in the production of malts for various purposes was studied before. Our task was to determine the effect of activated solutions on the process of obtaining the food sprouts and their microbiological status [21].

Activation of water and aqueous solutions by plasma-chemical treatment is the first step to using the properties of water without involvement of the artificial foreign chemicals of the different origin [20]. The resulting activated water has a specific composition. Reaction products, which determine the reactivity of such water, are the most easily detectable ones. This primarily applies to hydrogen peroxide and superoxide compounds, excited particles and radicals, which play an important role in redox processes. 


\section{Food Technology}

So, all processes which occur during activation are processes taking place directly in the aqueous medium [22]. Reactogenic properties of plasmochemically treated water represent priority subject for the scientists, because the properties of water arising after activation can be a starting point in the development of a new trend in nanotechnologies [23]. Plasmochemically activated water has antiseptic and antibacterial properties [24]. This water represents a cluster structure after plasma treatment and can exhibit some new properties, previously little studied, but important from the practical point of view [25, 26]. A special role in this case is given to studying of the influence of activated water on the parameters of some processes in food, biochemical and biotechnological productions [27]. One of such processes is the obtaining of food sprouts of legume crops.

Research objective is the determination of the effect of plasmochemically activated aqueous solutions on the process of production of food sprouts.

In order to achieve the above objective, the following tasks were solved: studying of the legume germination energy and capacity; control of the length of legume sprouts during germination and weight of their biomass; studying of the microbiological status of sprouts; determination of the content of amino acids and vitamins in sprouts; selection of the optimal parameters of plasma-chemical activation of aqueous solutions.

\section{Materials and methods}

\section{Materials}

The legume crops (peas, soybeans, chickpeas, kidney beans, lentils, beans, lupines) were taken as the grain raw materials for germination (production of sprouts). Plasmochemically activated aqueous solutions acted as the intensifier of the process of germination [20].

Four analytical groups were selected for research from all legume crops: 500 pcs. each for small legumes and 250 pcs. each for the larger ones [8].

\section{Plasma-chemical activation of the aqueous solutions}

Water was activated using the laboratory plasma-chemical unit (Fig. 1). Tap water was activated in plasma discharges of reduced pressure with the voltage of 1000-1200 V and current of 30.0-200.0 mA with the subsequent transition (with electrical conductivity increase) to the mode of non-equilibrium contact plasma with the following parameters: voltage from 400 to $600 \mathrm{~V}$ and current up to $150 \mathrm{~mA}$. The content (concentration) of hydrogen peroxide in the activated water was determined by iodometry [28].

The unit works as follows [20]: input voltage is supplied to step-up transformer; AC voltage from the secondary winding of the transformer is applied to the bridge rectifier and further pulsating DC voltage through the ballast resistor is supplied to the reactor electrodes. Additionally, the reactor anode is connected with the ignition device, which generates the pulses with the amplitude of up to $15 \mathrm{kV}$ and duration of up to $1.5 \mathrm{~ms}$. The pulses are rigidly synchronized with the phase of the pulsating voltage. At the time of formation of ignition pulse, breakdown of the vacuum space (created by pumping the gaseous phase from the reactor by the vacuum pump) occurs between electrodes of the reactor. There is a sharp drop in resistance; as a result, the anode current begins to flow, creating a discharge. The voltage of burning of the discharge is almost constant, at the level of 750-900 V, depending on the degree of gas liquefaction within the reactor. The magnitude of current of the discharge gap 
is conditioned by the plasma resistance and the value of voltage applied to the system plasma discharge - ballast regulator. The voltage value is regulated according to the phase method, i.e. average value of the anode voltage supplied to the reactor depends on the phase of pulsating voltage at the anode and the moment of feeding of the ignition pulse. Plasma occurs at the time of ignition and goes out at the end of the anode voltage ripple. The repetition frequency in the process is $100 \mathrm{~Hz}$. Regulation of the discharge current used in the device is carried out by changing the ignition moment relative to the phase of the anode voltage ripple using a synchronizing device. In this case, the reactor itself acts as a power-regulating unite. Parameters of the plasma discharge are recorded using the equipment of M4200 type, class 4.0.

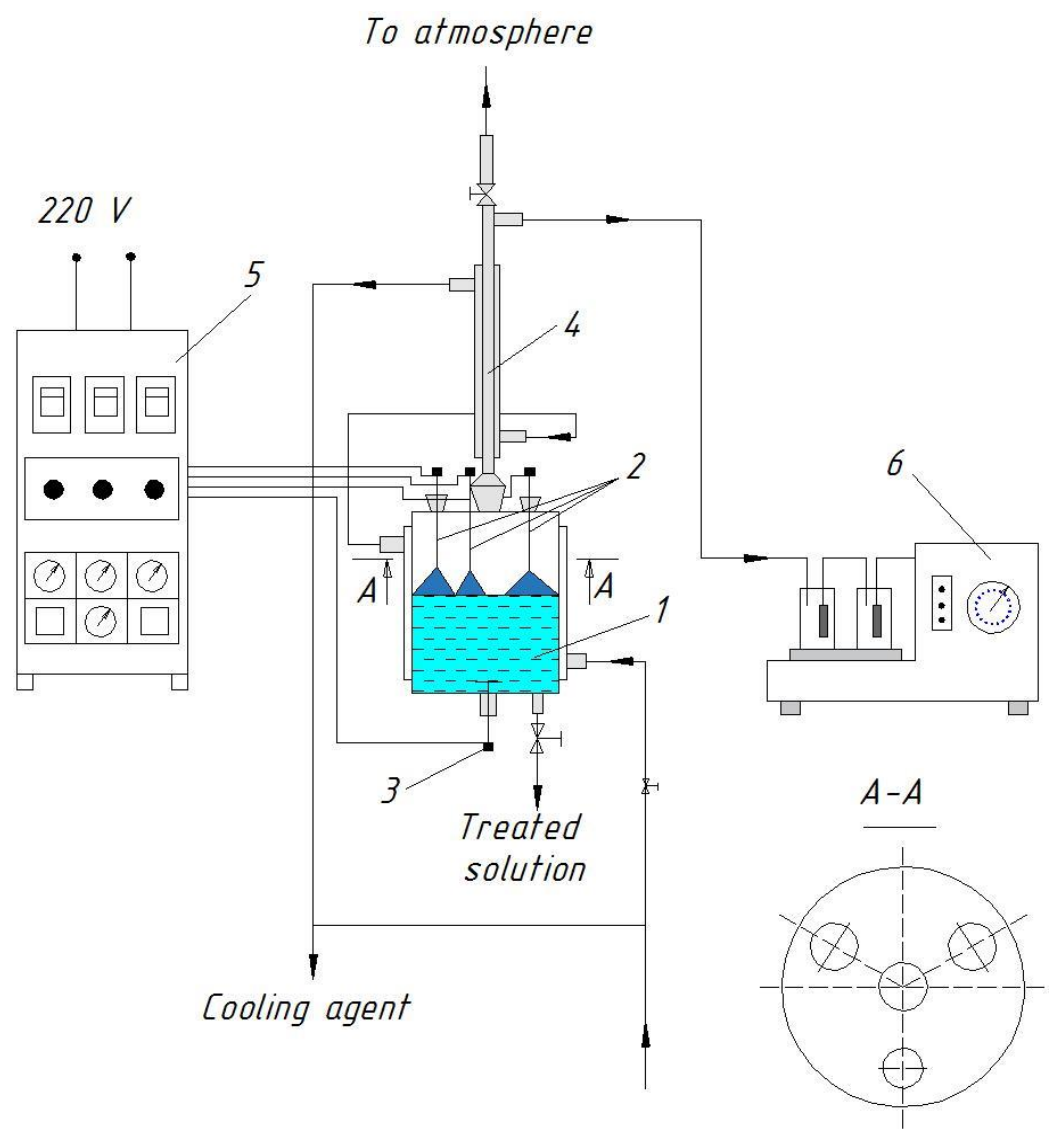

Figure 1. Diagram of the laboratory three-arc plasma-chemical unit: 1 - reactor; 2 - anodes; 3 - cathode; 4 - reflux condenser; 5 - power supply; 6 - vacuum pump.

Characteristic of the activated water used as an intensifier of germination during soaking of legumes is given in Table 1 . 
Characteristics of water activated by non-equilibrium contact plasma

\begin{tabular}{|c|c|c|c|}
\hline Experiment & Water & $\begin{array}{c}\text { Activation } \\
\text { time, minutes }\end{array}$ & $\begin{array}{c}\text { Concentration of } \\
\text { hydrogen peroxide, } \\
\text { mg/l }\end{array}$ \\
\hline 1 (control) & Tap water & - & - \\
\hline 2 & Activated water & 10 & 300 \\
\hline 3 & Activated water & 20 & 400 \\
\hline 2 & Activated water & 30 & 600 \\
\hline 4 & Activated water & 40 & 650 \\
\hline 5 & Activated water & 60 & 700 \\
\hline
\end{tabular}

\section{Sprouting of legumes with the use of plasmochemically activated aqueous solutions}

Grain of legumes was sprouted in the laboratory malt house representing a set of plastic containers covered with the layer of filter paper [29]. The grain material was treated with plasmochemically activated aqueous solutions (with the concentration of peroxides of 300 $700 \mathrm{mg} / \mathrm{l})$ as follows: legume crops prepared for germination were saturated with plasmochemically activated solutions in two stages. Pre-soaking was carried out for 4 hours at the temperature of $18-20{ }^{\circ} \mathrm{C}$ [12]. At the end of the period, the nutrient solution was drained, and the grain was held for 18 hours without access of the liquid. The activated solution of the similar concentration was used during repeated soaking. Air-and-water soaking was carried out for 26 hours till complete saturation of the grain with the preparation [11]. Germination was performed for 3-15 days at the temperature of $17-21^{\circ} \mathrm{C}$, with the periodical moistening and shaking of the grain layer of maximum $45-55 \mathrm{~mm}$ high, in order to evenly distribute the liquid and prevent agglomeration of the mass. Depending on the process needs, the final stage of the process was cooling, grinding or drying of sprouts [8].

Method for determination of the legume germination energy and capacity, length and weight of biomass of sprouts

Germination energy and capacity was determined for establishing the amount of legumes capable of forming the normally developed sprouts [30]. Together with the germination capacity, we determined the energy of legumes' germination, characterizing the rate of germination and sprout vigor. Capacity and energy of germination was expressed as a percentage of normally sprouted grain to the total quantity. Energy and capacity of germination of the grain material was determined, accordingly, on the expiry of 72 hours and 120 hours after completion of grain soaking [8]. These values were expressed in $\%$ to the total quantity of grains in the test sample. Effectiveness of selected intensifiers of growth was compared to the control, i.e. the grain not subjected to any chemical treatment. Besides, the length of sprouts was also measured to monitor the activity of grain germination and speed of sprout formation during 15 days. In parallel with it, the obtained biomass was weighed. All experiments were performed five times. 


\section{Method for determination of microbiological status of grain material in the process of germination}

The change in microbiological status of the grain material was observed under the microscope MBS-56, and inoculation of the nutrient medium with the wipe samples was made with the further counting of colonies of microorganisms [31].

\section{Analysis of the content of amino acids and vitamins}

In order to determine the nutrition value of the obtained product, we analyzed the amino acid content in legume sprouts, using for this purpose the method of ion-exchange liquid column chromatography [32]. The process of determination was performed on the automatic analyzer of amino acids T339 (Prague, Czech Republic) [9]. The vitamin composition of sprouts was also determined using ion-exchange liquid column chromatography and other standard methods [8].

\section{Results and discussion}

Studying of energy and capacity of germination of legume crops with the use of plasmochemically activated aqueous solutions

Germination energy and capacity are the important indicators of the process of legumes' germination (Table 2).

Table 2

Energy and capacity of germination of legumes with the use of plasmochemically activated aqueous solutions

\begin{tabular}{|c|c|c|c|c|c|c|}
\hline \multirow[t]{2}{*}{ Crops } & \multirow[t]{2}{*}{ Control } & \multicolumn{5}{|c|}{$\begin{array}{l}\text { Peroxide concentration in plasmochemically activated } \\
\text { aqueous solutions, } \mathrm{mg} / \mathrm{l}\end{array}$} \\
\hline & & 300 & 400 & 600 & 650 & 700 \\
\hline \multicolumn{7}{|c|}{ Germination energy } \\
\hline Peas & 80 & 85 & 92 & 89 & 86 & 83 \\
\hline Soybeans & 80 & 85 & 91 & 88 & 85 & 84 \\
\hline Chickpeas & 81 & 86 & 91 & 89 & 86 & 84 \\
\hline Kidney beans & 80 & 86 & 90 & 87 & 85 & 83 \\
\hline Lentils & 81 & 86 & 92 & 89 & 86 & 84 \\
\hline Beans & 80 & 85 & 90 & 87 & 86 & 83 \\
\hline Lupines & 80 & 84 & 91 & 88 & 84 & 82 \\
\hline \multicolumn{7}{|c|}{ Germination capacity } \\
\hline Peas & 91 & 94 & 99 & 96 & 94 & 93 \\
\hline Soybeans & 90 & 94 & 100 & 97 & 96 & 92 \\
\hline Chickpeas & 91 & 93 & 99 & 95 & 94 & 92 \\
\hline Kidney beans & 92 & 95 & 100 & 96 & 95 & 92 \\
\hline Lentils & 91 & 94 & 99 & 94 & 92 & 91 \\
\hline Beans & 90 & 94 & 99 & 95 & 93 & 91 \\
\hline Lupines & 91 & 95 & 100 & 96 & 94 & 92 \\
\hline
\end{tabular}




\section{Food Technology}

We observed the higher activity of germination in the experimental analytical groups compared to the control, which indicated the possibility of using plasmochemically activated water for intensification of the germination of legumes. A similar tendency was demonstrated by all crops under study. So, the germination energy and capacity increased, correspondingly, by $10-12 \%$ and $8-10 \%$. Optimal concentration of peroxides in the activated solutions was equal to $400 \mathrm{mg} / \mathrm{l}$. It is explained by the fact that activated water accelerates the inflow of moisture to the grain and, as a consequence, nutrients are transferred from the endosperm to the germ, stimulating its awakening to active life; it can accelerate the accumulation of cytolytic, proteolytic and amylolytic enzymes.

The chaotic motion of ions [27] in the activated water allows accelerating the diffusion of water into the grain due to more active inflow of charged particles to the grain surface. This aspect confirms the fact that with the use of activated water as a moisturizing agent, due to its specific composition, moisture is more actively transported into the grain. That is, the activated water quickly diffuses into the grain.

Hull of the grain contain the germination inhibitors impeding the grain germination at rest [33]. During soaking, they should be leached and removed. Since the activated water has an alkaline nature, with peroxide and superoxide compounds in its composition, their usage accelerates the leaching of substances, which inhibit the growth. Furthermore, the alkaline environment promotes leaching of tannins, bitter substances and proteins from the hull [18]. In addition, the alkaline solution promotes additional washing of the grain. Hydrogen peroxide being a part of the activated water acts as an oxidant and, as a result, improves the grain purification. On the other hand, it stimulates the grain germination at the time of oxygen release. The alkaline environment does not have any significant negative impact on the subsequent quality of sprouts [18].

Water is absorbed mainly through the vessels, which exit at the basal end of the grain [18]. After penetration of water into the grain, transfer of water from the endosperm to the germ begins. Migration of charged particles in the grain results in the inflow of negatively charged particles to the germ and outflow of positively charged particles. These processes increase the permeability of grain structures to water and nutrients. The capillary condensation occurs quickly, and the activated water is absorbed with the formation of condensate in the grain capillaries. In parallel with the increase in grain moisture, activity of amylases, ribonucleases and phosphatases (which are further broken down in the absence of oxygen) is growing [34]. Activated water contains hydro-peroxide radicals, which promote the oxygen formation leading to the further increase in the content of the above enzymes and more active breakdown of endosperm components. As a result, the intensification of legume germination can be observed. Therefore, duration of the technological process of obtaining the sprouts can be significantly reduced.

When we compare the results with the other studies $[8,35]$, it is necessary to note more active progress of the germination process, namely, increase in energy and capacity of germination by $2-3 \%$ compared to other intensifiers, representing undeniably positive result.

\section{Studying of the change of length and weight of biomass of legume sprouts with the use of plasmochemically activated aqueous solutions}

In order to monitor the change in the length of sprouts, they were measured in 72 hours after the start of the germination process. The averaged data by analytical groups are given in Table 3. 
Table 3

Change in the length of legume sprouts with the use of plasmochemically activated aqueous solutions, $\mathbf{m m}$

\begin{tabular}{|l|l|l|l|l|l|l|}
\hline \multirow{2}{*}{ Crop } & \multirow{6}{*}{ Control } & \multicolumn{6}{|l|}{$\begin{array}{l}\text { Peroxide concentration in plasmochemically activated } \\
\text { aqueous solutions, mg/l }\end{array}$} \\
\cline { 3 - 7 } & & $\mathbf{3 0 0}$ & $\mathbf{4 0 0}$ & $\mathbf{6 0 0}$ & $\mathbf{6 5 0}$ & $\mathbf{7 0 0}$ \\
\hline Peas & 17 & 22 & 31 & 29 & 25 & 22 \\
\hline Soybeans & 18 & 23 & 31 & 30 & 28 & 24 \\
\hline Chickpeas & 19 & 23 & 32 & 31 & 26 & 24 \\
\hline $\begin{array}{l}\text { Kidney } \\
\text { beans }\end{array}$ & 30 & 34 & 41 & 39 & 37 & 34 \\
\hline Lentils & 7 & 11 & 15 & 14 & 12 & 11 \\
\hline Beans & 42 & 48 & 54 & 52 & 50 & 48 \\
\hline Lupines & 12 & 15 & 18 & 17 & 16 & 14 \\
\hline
\end{tabular}

After analysis of our findings, we can make a conclusion about more intensive development of sprouts in all legume crops with the use of plasmochemically activated aqueous solutions during soaking. The optimal concentration of peroxides in the solutions was also equal to $400 \mathrm{mg} / \mathrm{l}$, so the activation modes for aqueous solutions were chosen correctly.

Dynamics of sprout formation was identical for all legume crops. Presented experimental data show that activation of growth processes with the use of plasmochemically activated aqueous solutions is observed absolutely in all legume crops under study.

Quantity of sprouts (biomass) [35] obtained after completion of the cycle of all process operations is an important indicator of the industrial production. The yield of the finished product, namely, legume sprouts with the use of plasmochemically activated solutions ranged from $4-16 \%$ depending on the legume crop (peas $-8 \%$; soybeans $-10 \%$; chickpeas $-7 \%$; kidney beans $-14 \%$; lentils $-4 \%$; beans $-16 \%$; lupines $-10 \%$ ). Therefore, the proposed intensive technology of sprout production will allow obtaining a larger amount of food product, which is a positive characteristic of the process.

\section{Studying of microbiological status of legume sprouts after treatment with plasmochemically activated aqueous solutions}

Plasmochemically activated aqueous solutions exhibit antiseptic properties, which further reduces the microbial contamination of sprouts and has a positive effect on the microbiological indicators of the finished product [20]. So, the sprouts were further treated with plasmochemically activated solutions for disinfection (Table 4). 
Table 4

Effect of plasmochemically activated aqueous solutions on the pathogenic complex of legume sprouts, \% of infected sprouts

\begin{tabular}{|c|c|c|c|c|c|c|c|c|c|}
\hline \multirow[t]{2}{*}{$\begin{array}{l}\text { Exposure, } \\
\text { minutes }\end{array}$} & \multirow{2}{*}{$\begin{array}{l}\text { Infection with } \\
\text { fungal } \\
\text { microflora }\end{array}$} & \multicolumn{8}{|c|}{$\begin{array}{l}\text { Peroxide concentration in plasmochemically } \\
\text { activated aqueous solutions, mg/l }\end{array}$} \\
\hline & & 0 & 100 & 200 & 300 & 400 & 500 & 600 & 700 \\
\hline \multirow{5}{*}{10} & Aspergillus & 98 & 70 & 30 & 8 & 0 & 0 & 0 & 0 \\
\hline & Alternaria & 30 & 28 & 10 & 5 & 0 & 0 & 0 & 0 \\
\hline & Penicillium & 25 & 7 & 5 & 2 & 0 & 0 & 0 & 0 \\
\hline & Fusarium & 6 & 2 & 1 & 0 & 0 & 0 & 0 & 0 \\
\hline & Mucor & 31 & 17 & 12 & 5 & 0 & 0 & 0 & 0 \\
\hline \multirow{5}{*}{20} & Aspergillus & 99 & 42 & 15 & 5 & 0 & 0 & 0 & 0 \\
\hline & Alternaria & 31 & 14 & 6 & 3 & 0 & 0 & 0 & 0 \\
\hline & Penicillium & 25 & 4 & 3 & 1 & 0 & 0 & 0 & 0 \\
\hline & Fusarium & 6 & 1 & 0 & 0 & 0 & 0 & 0 & 0 \\
\hline & Mucor & 39 & 11 & 4 & 2 & 0 & 0 & 0 & 0 \\
\hline \multirow{5}{*}{30} & Aspergillus & 99 & 19 & 8 & 2 & 0 & 0 & 0 & 0 \\
\hline & Alternaria & 32 & 6 & 3 & 1 & 0 & 0 & 0 & 0 \\
\hline & Penicillium & 26 & 2 & 1 & 0 & 0 & 0 & 0 & 0 \\
\hline & Fusarium & 6 & 1 & 0 & 0 & 0 & 0 & 0 & 0 \\
\hline & Mucor & 42 & 7 & 3 & 1 & 0 & 0 & 0 & 0 \\
\hline \multirow{5}{*}{40} & Aspergillus & 99 & 9 & 3 & 1 & 0 & 0 & 0 & 0 \\
\hline & Alternaria & 33 & 2 & 1 & 0 & 0 & 0 & 0 & 0 \\
\hline & Penicillium & 26 & 1 & 0 & 0 & 0 & 0 & 0 & 0 \\
\hline & Fusarium & 6 & 0 & 0 & 0 & 0 & 0 & 0 & 0 \\
\hline & Mucor & 43 & 3 & 1 & 0 & 0 & 0 & 0 & 0 \\
\hline \multirow{5}{*}{50} & Aspergillus & 99 & 3 & 1 & 0 & 0 & 0 & 0 & 0 \\
\hline & Alternaria & 33 & 1 & 0 & 0 & 0 & 0 & 0 & 0 \\
\hline & Penicillium & 27 & 1 & 0 & 0 & 0 & 0 & 0 & 0 \\
\hline & Fusarium & 7 & 0 & 0 & 0 & 0 & 0 & 0 & 0 \\
\hline & Mucor & 43 & 2 & 0 & 0 & 0 & 0 & 0 & 0 \\
\hline \multirow{5}{*}{60} & Aspergillus & 100 & 1 & 0 & 0 & 0 & 0 & 0 & 0 \\
\hline & Alternaria & 33 & 1 & 0 & 0 & 0 & 0 & 0 & 0 \\
\hline & Penicillium & 27 & 0 & 0 & 0 & 0 & 0 & 0 & 0 \\
\hline & Fusarium & 7 & 0 & 0 & 0 & 0 & 0 & 0 & 0 \\
\hline & Mucor & 43 & 0 & 0 & 0 & 0 & 0 & 0 & 0 \\
\hline
\end{tabular}


Consequently, when using the activated aqueous solutions the quantity of infected sprouts is significantly reduced. At the concentration of peroxides of $400 \mathrm{mg} / \mathrm{l}$, pathogenic microorganisms are completely absent. One possible mechanism of action of the activated water on bacteria is the change in outer layers of the cell, which makes the receptors accessible for reactogenic enzymes, such as lysozyme. Free radicals can form a gap in the cell wall, which leads to the loss of selective permeability [31]. Peroxide being a part of the activated water causes the destruction of surface structures and internal membranes in microorganisms [20]. Integrity of the cytoplasmic membrane disrupts the functions of a number of membrane-related enzymes, such as dehydrogenases, and reduces the efficiency of the DNA repair systems. Bactericidal activity of the hydrogen peroxide and activated water is primarily associated with their high oxidation capacity, as well as action of toxic products, which arise during lipid peroxidation [21]. Peroxidation affects the ribosome proteins, causing their destruction. Furthermore, destruction of the membrane structure is promoted by the formed superoxides [20]. The action of the hydrogen peroxide or activated water results in the local destruction of the integral cell wall and disruption of permeability of the bacterial cells in the first minutes of contact. The peculiar feature of the activated water is also the selective ability to directly destroy the pathogenic microflora [36]. Therefore, the result of the use of plasmochemically activated aqueous solutions is the microbiological purity of sprouts [37], which allows consuming them without the additional heat treatment.

Analysis of microbiological indicators of sprouts, compared to the other studies [36,37], allow saying about the stable disinfecting ability of plasmochemically activated aqueous solutions.

Studying of the content of amino acids and vitamins in sprouts obtained with the use of plasmochemically activated aqueous solutions

The vitamin composition of legume sprouts varied with the use of plasmochemically activated aqueous solutions; results are given in Table 5.

Table 5

Average vitamin composition of legume sprouts obtained according to the intensive technology, mg\%

\begin{tabular}{|c|c|c|c|c|c|c|}
\hline \multirow[t]{2}{*}{ Vitamins } & \multirow[t]{2}{*}{ Control } & \multicolumn{5}{|c|}{$\begin{array}{l}\text { Peroxide concentration in plasmochemically activated } \\
\text { aqueous solutions, } \mathrm{mg} / \mathrm{l}\end{array}$} \\
\hline & & 300 & 400 & 600 & 650 & 700 \\
\hline $\mathrm{B}_{1}$ & 0.620 & 0.679 & 0.687 & 0.680 & 0.675 & 0.671 \\
\hline $\mathrm{B}_{2}$ & 0.641 & 0.655 & 0.669 & 0.661 & 0.658 & 0.652 \\
\hline $\mathrm{B}_{3}$ & 1.871 & 1.879 & 1.887 & 1.881 & 1.875 & 1.870 \\
\hline $\mathrm{B}_{6}$ & 0.535 & 0.549 & 0.562 & 0.550 & 0.548 & 0.541 \\
\hline $\mathrm{B}_{12}$ & 0.511 & 0.521 & 0.528 & 0.520 & 0.518 & 0.512 \\
\hline $\mathrm{PP}$ & 0.303 & 0.311 & 0.319 & 0.314 & 0.311 & 0.307 \\
\hline$E$ & 1.322 & 1.333 & 1.350 & 1.341 & 1.339 & 1.331 \\
\hline $\mathrm{C}$ & 6.225 & 6.238 & 6.265 & 6.242 & 6.241 & 6.235 \\
\hline $\mathrm{A}$ & 2.591 & 2.629 & 2.679 & 2.654 & 2.650 & 2.631 \\
\hline
\end{tabular}


For example, with the use of the proposed process intensifier, the content of vitamins in legume sprouts increased. The maximum quantities of vitamins is observed at the peroxide concentration of $400 \mathrm{mg} / \mathrm{l}$. This is due to the activation of all biological processes in the grain in the course of construction of a sprout, since the formation of a new plant takes place [38]. As the plasmochemically activated aqueous solutions intensify the process of germination and sprout formation, the results are understandable and quite logical.

The content of amino acids in legume sprouts was also studied. The maximum number of amino acids in sprouts is observed at the peroxide concentration of $400 \mathrm{mg} / \mathrm{l}$. So, the number of amino acids with the use of plasmochemically activated aqueous solutions increased. The content has grown by: lysine $-9-18 \%$; histidine $-12-17 \%$; arginine $-6-7 \%$; aspartic acid -9-10\%; threonine -20-22\%; serine - 15-16\%; glutamic acid - 4-5\%; proline - 5-6\%; glycine -51-52\%; alanine $-12-14 \%$; cystine - 50-52\%; valine $-27-28 \%$; methionine $-51-52 \%$; isoleucine $-12-14 \%$; leucine $-10-12 \%$; tyrosine $-11-12 \%$; phenylalanine $-14-16 \%$; glutamine $-7-8 \%$. Therefore, compared to the control sample, amino acid content increased by $4-52 \%$. It is explained by more intensive development of sprouts, during which amino acids accumulate more actively [39], since they participate in the formation of the future plant.

Studying of the vitamin and amino acid composition of sprouts compared to the other studies [35, 39] suggests the higher level of vitamins and amino acids in the legume sprouts with the use of plasmochemically activated aqueous solutions. It allows saying about the increased biological value of the finished product.

\section{Conclusions}

1. Indicators of germination of legumes were studied with the use of plasmochemically activated aqueous solutions: germination energy and capacity increased, correspondingly, by $10-12 \%$ and $8-10 \%$.

2. Monitoring of the sprout length showed the increase in length from 6 to $14 \mathrm{~mm}$. Weight of sprouts increased by $4-16 \%$, depending on the crop.

3. Study of the microbiological status of sprouts showed the pronounced disinfecting action of plasmochemically activated aqueous solutions with peroxide concentration of $400 \mathrm{mg} / \mathrm{l}$ and more.

4. Study of the amino acid composition demonstrated the higher content of amino acids in sprouts (by 4-52\%). We also observed the increase in the content of vitamins $\mathrm{B}_{1}, \mathrm{~B}_{2}$, $\mathrm{B}_{3}, \mathrm{~B}_{6}, \mathrm{~B}_{12}$, PP, E, C, A in legume sprouts with the use of plasmochemically activated aqueous solutions.

5. Plasmochemically activated aqueous solutions with peroxide concentration of $400 \mathrm{mg} / \mathrm{l}$ are optimal for use in the process of legume sprouts' production. Usage of the proposed intensifier allows obtaining high-quality product with the increased content of vitamins and amino acids in the shorter time. In addition, the resulting product is free of pathogenic microorganisms.

\section{References}

1. Hübner F., Arendt E.K. (2013), Germination of cereal grains as a way to improve the nutritional value: A review, Critial Reviews in Food Science and Nutrition, 53(8), pp. 853861, DOI: $10.1080 / 10408398.2011 .562060$ 


\section{- Food Technology -}

2. Butenko L.I., Legai L.V. (2013), Researches of the chemical composition of germinated seeds of the buckwheat, oats, barley and wheat, Fundamental research, 4(5), pp. 1128-1133.

3. Myachikova N.Y., Binkovskaya O.V., Chizhova S.V., Rudycheva E.V. (2012), Use of Germinated Seeds in The Foodstuff. Izvestyiya VUZOV, Prikladnaya ximiya i biotexnologiya, 2(3), pp. 149-152.

4. Kovaliova O., Tchursinov Y., Kalyna V., Khromenko T., Kunitsia E. (2020), Investigation of the intensive technology of food sprouts using organic acids, «EUREKA: Life Sciences». Food Science and Technology, 2, pp. 45-53, DOI: DOI:10.21303/2504-5695.2020.001204

5. Agu R.C., Devenny D.L., Palmer G.H. (2002), Malting performance of normal huskless and acid-dehusked barley samples. The Extract Factory, Scotmalt Ltd, Kirkiston, West Lothian, Edinburgh, 2, pp. 215-220, DOI: DOI:10.1002/j.2050-0416.2002.tb00543.x

6. Lewis M.J., Young T.W. (2001), Malting technology: malt, specialized malts and non-malt adjuncts, Boston: Aspen Publishers Inc, pp. 163-190, DOI: DOI:10.1007/978-1-46151801-3_4.

7. Pivovarov O.A, Koval'ova O.S. (2020), Suchasni metodi intensifikaciï solodoroshchennya: monografiya, Dnipro.

8. Kovaliova O., Tchursinov Yu., Kalyna V., Koshulko V., Kunitsia E., Chernukha A., Bezuglov O., Bogatov O., Polkovnychenko D., Grigorenko N. (2020), Identification of patterns in the production of a biologically-active component for food products, EasternEuropean Journal of Enterprise Technologies, 2/11(104), pp. 61-68, DOI: 10.15587/17294061.2020.200026

9. Szwajgier D., Pielecki J., Targonski Z. (2005), Changes of free ferulic and coumaric acid contents during malting of barley grain, Lublin: Polish Journal of Food and Nutrition Sciences, 4(14), pp. 423-429.

10. Tchursinov Ju.A., Kovaleva E.S., Koshul'ko V.S., Kalina V.S., Prished'ko V.M. (2020), Bioaktivacija zerna $\mathrm{s}$ ispol'zovaniem fruktovyh kislot, Vestnik rossijskoj sel'skohozjajstvennoj nauki, 2, pp. 26-28, DOI: 10.30850/vrsn/2020/2/26-28

11. Pivovarov O., Kovaliova O., Khromenko T., Shuliakevych Z. (2017), Features of obtaining malt with use of aqueous solutions of organic acids, Food Science and Technology, 11(4), pp. 29-35, DOI: 10.15673/fst.v11i4.728

12. Pivovarov O., Kovaliova O. (2019), Features of grain germination with the use of aqueous solutions of fruit acids, Food Science and Technology, 13(1), pp. 83-89, DOI: 10.15673/fst.v13i1.1334

13. Tchursinov YU.A., Kovaleva E.S. (2019), Primenenie organicheskih kislot i ih smesej v kachestve stimulyatora prorastaniya semennogo materiala, Vestnik rossijskoj sel'skohozyajstvennoj nauki, 6, pp. 31-34, DOI: 10.30850/vrsn/2019/6/31-34

14. Guoping Z, Chengdao L. (2010), Genetics and Improvement of Barley Malt Quality, NY, DOI 10.1007/978-3-642-01279-2

15. Narzib L., Back W., Gastl M., Zarnkow M. (2017), Abriss der Bierbrauerei, Wiley-VCH, DOI: $10.1002 / 9783527812820$.

16. Shishkova Yu.S., Simonyan E.V., Abramovskikh O.S., et al. (2014), The study of antimicrobial activity of some dibasic carboxylic acids in combination with propolis, Medical Almanac, 1 (31), pp. 99-101.

17. Khodunova O.S., Silant'eva L.A. (2017), Provision of microbiological safety of oat seed germination, Foods and Raw Materials, 5(2), pp. 145-150, DOI: 10.21603/2308-40572017-2-145-150

18. Meledina T. V., Prohorchik I. P., Kuznecova L. I. (2013), Biohimicheskie processy pri proizvodstve soloda, Sankt-Peterburg.

19. Hosni R. K. (2006), Nauchnye osnovy i tehnologii pererabotki zerna, Professija, SPb.

20. Pivovarov A.A., Tishhenko A.P. (2006), Neravnovesnaja plazma: processy aktivacii vody $i$ vodnyh rastvorov, DS-Print, Dnipropetrovsk. 


\section{- Food Technology}

21. Mahendra R, Yadav A., Gade A. (2009), Silver nanoparticles as a new generation of antimicrobials, Biotechnology Advances, 27, pp. 76-83.

22. Krutyakov Yu. A., Kudrinskiy A. A., Olenin A. Yu., Lisichkin G. V. (2008), Synthesis and properties of silver nanoparticles: advances and prospects, Russ Chem Rev, 77, pp. 233-257.

23. Kholoud M. M., Abou Eftaiha E., Al-Warthan A., Ammar R. (2010), Synthesis and applications of silver nanoparticles, Arabian Journal of Chemistry, 3, pp.135-140.

24. Qin Y., Ji X., Jing J., Liu H., Wu H., Yang W. (2010), Size control over spherical silver nanoparticles by ascorbic acid reduction, Colloids and Surfaces A: Physicochem Eng. Aspects, 372, pp. 172-176.

25. Goncharuk V.V. (2014), Water Clusters, Drinking Water: Physics, Chemistry and Biology, Springer International Publishing, pp. 51-103.

26. Beckstedte M., Kley A., Neugebaue J., Scheffler M. (1997), Density functional theory calculations for poly-atomic systems: electronic structure, static and elastic properties and ab initio molecular dynamics, Comp. Phys. Commun, 107, pp. 187-205.

27. Aider M., Kastyuchik A., Gnatko E., Benali M., Plutakhin G. (2012), Electro-activated aqueous solutions: theory and application in the food industry and biotechnology, Innovative Food Science \& Emerging Technologies, 15, pp. 38-49.

28. Melet'ev A.E., Todosijchuk S.R., Koshova V.M. (2007), Tekhnohimichnij kontrol' virobnictva solodu, piva i bezalkogol'nih napoüv, Nova Kniga, Vinnicya.

29. Urbano G., Aranda P., Vilchez A., Aranda C., Cabrera L., Porres J., Lopez-Jurado M. (2005), Effects of germination on the composition and nutritive value of proteins in Pisum sativum L., Food Chemistry, 93, pp.671-679.

30. Sangronis E., Machado C. J. (2007), Influence of germination on the nutritional quality of Phaseolus vulgaris and Cajanus cajan, LWT, 40, pp. 116-120.

31. Martinez-Sanchez A., Allende A., Bennett R. N., Ferreres F., Gil M. I. (2006), Microbial, nutritional and sensory quality of Rocket leaves as affected by different sanitizers, Postharvest Biology and Technology, 42, pp. 86-97.

32. Rozan P., Kuo Y. H., Lambein F. (2001), Amino acids in seeds and seedlings of the genus Lens, Phytochemistry, 58, pp. 281-289.

33. Fernandez-Orozco R., Piskula M. K., Zielinski H., Kozlowska H., Frias J., Vidal-Valverde C. (2006), Germination as a process to improve the antioxidant capacity of Lupinus angustifolius L. var. Zapaton, European Food Research and Technology, 223, pp. 495-502.

34. Amici M., Bonfili L., Spina M., Cecarini V., Calzuola I., Marsili V., Angeletti M., Fioretti E., Tacconi R., Gianfranceschi G. L., Eleuteri A. M. (2008), Wheat sprout extract induces changes on 20S proteasomes functionality, Biochimie, 90, pp. 790-801.

35. Kovaliova O., Tchursinov Y., Kalyna V., Khromenko T., Kunitsia E. (2020), Investigation of the intensive technology of food sprouts using organic acids, «EUREKA: Life Sciences». Food Science and Technology, 2, pp. 45-53, DOI: 10.21303/2504-5695.2020.001204

36. Fahey J. W., Ourisson P. J., Degnan F. H. (2006), Pathogen detection, testing, and control in fresh broccoli sprouts, Nutrition Journal, 5, pp. 13, Available at: http://www.nutritionj.com/content/5/1/13

37. Ho C. Y., Lin Y. T., Labbe R. G., Shetty K. (2006), Inhibition of Helicobacter pylori by phenolic extracts of sprouted peas (Pisum sativum L.), Journal of Food Biochemistry, 30, pp. 21-34.

38. Doblado R., Frias J., Vidal-Valverde C. (2007), Changes in vitamin C content and antioxidant capacity of raw and germinated cowpea (Vigna sinensis var. carilla) seeds induced by high pressure treatment, Food Chemistry, 101, pp. 918-923.

39. Urbano G., Lopez-Jurado M., Frejnagel S., Gomez-Villalvaa E., Porres J. M., Frias H., Vidal-Valverde C., Aranda P. (2005), Nutritional assessment of raw and germinated pea (Pisum sativum L.) protein and carbohydrate by in vitro and in vivo techniques, Nutrition, 21, pp. 230-239. 